\title{
Phytochemical profile, anti-inflammatory, antimutagenic and antioxidant properties of Acrocomia aculeata (Jacq.) Lodd. pulp oil
}

\author{
Gleicieli Libório Alencar COSTA ${ }^{1}$, Danieli Fernanda BUCCINI ${ }^{1}$, Ana Lucia Alves ARRUDA ${ }^{1}$, \\ Simone Palma FAVARO ${ }^{1,2}$, Susana Elisa MORENO ${ }^{1 *}$
}

\begin{abstract}
Acrocomia aculeata, known as macauba, is extensively distributed in the Southeast and Midwest of Brazil. Macauba fruit is used as food; however, its therapeutic properties are still poorly understood. The goal of the study was to investigate the chemical composition of macauba pulp oil (MPO) and anti-inflammatory, antimutagenic and antioxidant properties of MPO. The anti-inflammatory and antimutagenic properties were evaluated in Swiss mice treated with MPO per gavage or incorporated in the diet for 10 days. The serum of mice was subjected to lipid peroxidation evaluation and the in vitro MPO antioxidant activity was assessed. The organoleptic profile of MPO showed it was suitable for consumption and this composition showed unsaturated fatty acids with oleic acid the most abundant. The MPO presented anti-inflammatory properties, inducing a decrease in the migration of neutrophil and mononucleate cells to the peritoneal cavity of mice; it also inhibited the formation of micronuclei in mice. Furthermore, MPO presented antioxidant activity and high carotenoid content. Our data support the hypothesis that MPO has anti-inflammatory and antimutagenic properties, and these effects can correlate with fatty acid profile and antioxidant compounds. There is great potential for the application of MPO for nutritional purposes.
\end{abstract}

Keywords: macauba; micronucleus; leukocyte migration; fatty acid; antioxidants.

Practical Application: The assurance of harmlessness and health benefits of the MPO will contribute to increase the macauba chain production and launch this oil in the market.

\section{Introduction}

The benefits of plant oils for human health have long been the focus of investigations, especially in recent decades when they replaced some animal oils in food. Vegetable oils such as olive, palm, soy, corn, sunflower and canola are a common dietary constituent and consumed in high quantities worldwide (Esfahani et al., 2011). Some of these oils, such as olive oil, have presented beneficial properties for human health, due to the presence of antioxidant compounds, such as polyphenols, tocopherols and fatty acids (Covas et al., 2006; Poveda et al., 2005; Ju et al., 2010), such as oleic and linoleic acids (Estruch et al., 2013).

In Brazil, there are 119 species of palms, distributed in 39 genera (Scariot et al., 1995). The genus Acrocomia comprises many species, such as Acrocomia aculeata (Jacq.) Lodd., which grows in the Southeast and Midwest of Brazil (Henderson et al., 1995). The fruit of A. aculeata, known as macauba, is widely consumed; however, its therapeutic properties are poorly understood. A. aculeata fruits are rich in flavonoid antioxidants, $\beta$-carotene and tocopherols, and the fatty acid profile in macauba pulp oil (MPO) is composed mostly of monounsaturated, such as oleic acid (Coimbra \& Jorge, 2011; Lescano et al., 2015). This profile suggests that the consumption of the oil obtained from the macauba can be healthy. However, oil composition may be different according to genetic factors and abiotic factors such as light, temperature, precipitation, nutrition, season and time of collection and harvesting techniques (Singer et al., 2016).

A. aculeata pulp fruit has long been used in folk medicine as laxative, whereas its oil has analgesic and healing properties. However, the beneficial pharmacological effects of A. aculeata oil to human health are still scarce. Nunes et al. (2018) demonstrated that the A. aculeata kernel oil presents hypoglycemic effects, decrease in weight gain and deposition of medium chain fatty acids in the epididymal adipose tissue in diabetic rats, suggesting that $A$. aculeata oil is a promising source of energy in diets to type 2 diabetes mellitus patients (Nunes et al., 2018). In addition, Silva et al. (2019) also have recently demonstrated that $A$. aculeata pulp oil decreased glucose levels induced by a rich fructose-diet or by streptozotocin administration in rats (Silva et al., 2019). Supporting evidence to the beneficial effects of MPO shows that it can reduce total cholesterol levels and exhibits antioxidant activities (Nunes et al., 2018; Arena et al., 2018). These observations suggest that pharmacological properties of MPO should be further explored to provide new basis for its nutritional and medical use. In this study, we showed the physicochemical profile of MPO and determined its anti-inflammatory, antimutagenic and antioxidant properties in a mice model. 


\section{Materials and methods}

\subsection{Source of chemicals: plant materials and extraction}

Ripe Acrocomia aculeata fruits were collected in a cultivation area of this species in Mato Grosso do Sul State, Central-West region of Brazil (coordinates $22^{\circ} 24^{\prime} 59^{\prime \prime} \mathrm{N}, 54^{\circ} 14^{\prime} 16^{\prime \prime} \mathrm{W}$ ). The formal identification of the plant material used in your study was confirmed by Dr. Simone Palma Favaro (no voucher specimen was deposited in herbarium). The access to botanical material is registered in the Management System of Genetic Patrimony and Associated Traditional Knowledge - SISGEN, Brazil ( $n^{\circ}$. A623CA8). Acrocomia aculeata pulp oil was provided by the Biotechnology Laboratory of the UCDB. Macauba fruits were harvested in December in the mid-western region of Brazil (coordinates $22^{\circ} 24^{\prime} 59^{\prime \prime} \mathrm{N}, 54^{\circ} 14^{\prime} 16^{\prime \prime} \mathrm{W}$ ). Fruits were gathered from five plants, around $100 \mathrm{~kg}$, and the bulk was used to the pulp oil extraction process. Rotten fruits were discarded. A sample of $20 \mathrm{~kg}$ of the selected fruits were washed with distilled water and immediately dried in a forced air circulation oven at $40{ }^{\circ} \mathrm{C}$ for $3 \mathrm{~h}$. The fruits were depulped using a stainless-steel knife. The pulp was dried in a forced air circulation oven at $60{ }^{\circ} \mathrm{C}$ until moisture around $10 \%$ was attained. The yield of the oil was 32\% in dry basis. Macauba Pulp Oil (MPO) was obtained using Soxhlet apparatus with hexane as organic solvent, which was removed in a rotary evaporator at $40{ }^{\circ} \mathrm{C}$.

\subsection{Physicochemical properties of the MPO}

The pulp oil was characterized by determining the acidity (oleic acid \%), iodine and peroxide values, according to the AOCS method (American Oil Chemists' Society, 2004). As an indication of the formation of primary compounds of oxidation, we determined the molar absorptivity at 232 and $270 \mathrm{~nm}$ in an AquaMate spectrophotometer, model v.4.55, according to the IUPAC method (Paquot, 1979) using isooctane as solvent (UV-IR-HPLC). The fatty acid profile was determined by gas chromatography with a flame ionization detector (Agilent Technologies 6890N). The fatty acids methyl esters produced with the boron trifluoride catalyst (BF3) were evaluated under the following conditions: injector temperature of $225^{\circ} \mathrm{C}$, detector temperature of $285^{\circ} \mathrm{C}$, column temperature $(\mathrm{HP}-88100 \mathrm{~mm} \times 0.250 \mathrm{~mm})$ initial $170^{\circ} \mathrm{C}$ for $2 \mathrm{~min}$, ramp $7^{\circ} \mathrm{C} / \mathrm{min}$ to a final temperature of $210^{\circ} \mathrm{C} / 29 \mathrm{~min}$, split ratio 200:1, hydrogen flow $40 \mathrm{~mL} / \mathrm{min}$, air flow $450 \mathrm{~mL} / \mathrm{min}$, helium flow $40 \mathrm{~mL} / \mathrm{min}$, injection volume $2 \mu \mathrm{L}$.

Quantification of total carotenoids was performed by diluted oil in petroleum ether, and absorbance was measured in $450 \mathrm{~nm}$, using the absorptivity of $\beta$-carotene in petroleum ether (2592) to determine concentration. The analyses were performed in triplicate (Rodriguez-Amaya \& Kimura, 2004).

\subsection{Animals and biological assays with Acrocomia aculeata oil}

\section{Animals and animal care}

For the execution of the experimental procedures, male and female Swiss mice weighing 18-22 g (6 weeks) were obtained at the Animal Facility of Universidade Católica Dom Bosco (UCDB). The animals were kept in ventilated rack at constant temperature $\left(23^{\circ} \mathrm{C}\right)$ in a light/dark cycle, with free access to feed and water and were acclimated for a week before experiments (Ethics Committee authorization: 005/2011.

\subsection{MPO incorporation into feed}

The MPO was incorporated into conventional food (Labina, Purina, Brazil) in three concentrations (5, 10 and 20\% w/w). Briefly, the food was macerated and the oil $(5,10$ and $20 \%)$ was incorporated. After, the moisture was $\operatorname{dry}\left(40^{\circ}\right)$ and pelletizing. The modified feed was offered to the mice over 10 days, ad libitum.

\subsection{Experimental design}

Animals $(n=5)$ were treated with MPO $(50 \mu \mathrm{L}$, gavage $)$ or saline, for 10 days and fed with the conventional diet. Aiming to evaluate the effect of MPO on diet, mice were fed with conventional or modified feed (5,10 and 20\% MPO) for 10 days. On the 11 th day, the animals underwent antimutagenic and anti-inflammatory assays. For the antimutagenic evaluation, mice were pre-treated with colchicine $(0.5 \mathrm{mg} / \mathrm{kg}$, intraperitoneally), a mutagenic drug (Paquot, 1979) or vehicle (saline). After 24 hours, the micronucleus number was evaluated in erythrocytes (caudal vein). For the investigation of the anti-inflammatory effect of MPO, mice were injected (i.p.) with thioglycolate $4 \%(500 \mu \mathrm{L}$; Merck, USA) or vehicle (saline). After 6 hours, the leukocyte migration evaluation was performed as described below. The euthanasia of the animals in the procedures was done by increasingly graded anesthesia (Ketamine $150 \mathrm{mg}$. $\mathrm{kg}^{-1}$ (Dopalen, CEVA/Brazil) and Xilazine $15 \mathrm{mg} . \mathrm{kg}^{-1}$ (Anasedan, CEVA/Brazil) and subsequently animals were submitted to cervical dislocation. The death was confirmed by cessation of respiration and heartbeat, and absence of reflexes.

\subsection{Anti-inflammatory assay: leukocyte migration into mice peritoneal cavity}

The mice were euthanized by deepening anesthesia; the peritoneal cavity was washed with $3 \mathrm{~mL}$ of PBS plus EDTA $(5 \% \mathrm{w} / \mathrm{v})$ and the exudate collected. The total cell count took place in a Neubauer chamber. The differential leukocyte counts were performed in panotic stained slides (Laborclin, Brazil), and were examined in optical microscope (Nikon ${ }^{\circledR}$ Eclipse $80 \mathrm{i}$, Oil immersion lens, 100/1.25). The results were expressed as number of mononucleate cells and neutrophils $\times 10^{6} / \mathrm{mL}$ (Moreno et al., 2006).

\subsection{Evaluation of antimutagenic activity of MPO: micronucleus test}

The micronuclei were analyzed in erythrocytes in peripheral blood. Two slides were prepared by drawing a drop of mouse blood over the slide to form a thin smear which was air-dried for $24 \mathrm{~h}$, fixed in methanol for $10 \mathrm{~min}$ and stained for $40 \mathrm{~min}$ with $5 \%(w / v)$ Giemsa stain. For each slide, 2000 erythrocytes were examined at $1000 \mathrm{X}$ magnification and scored under light microscope (Nikon ${ }^{\circledR}$ Eclipse 80i, Oil immersion lens, 100/1.25). For the scoring of micronuclei, the criteria from Al-Sabti \& Metcalfe (1995) were adopted. 


\subsection{Evaluation of the antioxidant activity of the MPO}

\section{Lipid peroxidation by TBARS assay}

Lipid peroxidation was studied in incubations $(2 \mathrm{~mL}$ final volume in $\left.\mathrm{PBS}, \mathrm{pH} 7.4,37^{\circ} \mathrm{C}\right)$, containing plasma $(200 \mu \mathrm{L})$ obtained from blood collected through the caudal vein of treated and non-treated mouse groups. Control samples were treated with the same volume of DMSO used to dilute antioxidants (the final dilution of DMSO was 1/1000). After 30 minutes' incubation at $100{ }^{\circ} \mathrm{C}$, lipid peroxidation was measured as the formation of TBARS, as previously described (Atmaca, 2004). Results were expressed in $\mu$ moles of MDA/mg serum.

\subsection{Hydroxyl radical scavenging activity assay}

In order to evaluate the hydroxyl radical scavenging activity of MPO, oil and standard ascorbic acid solutions were diluted in DMSO and methanol, respectively, at a concentration of $50 \mu \mathrm{g} / \mathrm{mL}$, diluted to 5,10 and $25 \mu \mathrm{g} / \mathrm{mL}$. The assay was carried out as described by Smirnoff \& Cumbes (1989). The absorbance of hydroxylated salicylate complex was measured at $562 \mathrm{~nm}$. Analyses were performed in triplicate and the results were expressed as percentage of antioxidant activity (AA\%).

\subsection{Antioxidant activity by $\beta$-carotene/linoleic acid system}

Initially, the MPO and BHT standard solutions were prepared in DMSO and ethanol at a concentration of $50 \mu \mathrm{g} / \mathrm{mL}$ as per the methodology described by Marco (1968) modified by Hammerschmidt \& Pratt (1978). BHT was used as a positive control at the same concentration, and ethanol was used as a blank. Analyses were performed in triplicate and the absorbance recorded at intervals of $20 \mathrm{~min}(20,40,60 \mathrm{~min})$.

\subsection{Statistical analysis}

Data analysis and graphic representation was performed by GraphPad Prism 6.0 program. The data are reported as the means \pm standard errors of the means (SEM) of values obtained from two different experiments. The means of different treatments were compared by analysis of variance (ANOVA). If significance was determined, individual comparisons were subsequently tested with Bonferroni's $t$ test for unpaired values. A $p$ value of 0.05 or less was considered significant.

\section{Results}

\subsection{Physicochemical properties, stability, quality and fatty acid profile of MPO}

Physical-chemical properties of a given vegetable oil can vary according to the region of cultivation, maturation stadium, storage length and conditions, genetic variability, processing method, among other factors. The MPO assessed in this study showed acidity and peroxide indexes of $2.47 \%$ and $9.28 \mathrm{mEq} / \mathrm{kg}$, respectively (Table 1). These values indicate that MPO is within the range established to other similar oils, though the high peroxide value. Also, the MPO iodine value found in this work was $72.01 \pm 2.22$, as demonstrated in Table 1 . In order to provide information about their identity, conservation status and changes caused by processing, spectrophotometric analysis of MPO using ultraviolet wavelength was performed. The MPO showed absorptivity at 232 and 2700 of the MPO, and the values were $2.49 \pm 0.04$ and $0.64 \pm 0.01$ respectively (Table 1 )

Fatty acid profile of MPO is shown in Table 2. Twelve fatty acids were identified, the majority of them unsaturated fatty acids with oleic acid the most abundant (72\%). There was also demonstrated that MPO contains high concentrations of total carotenoids expressed as $\beta$-carotene $(694 \pm 8.31 \mu \mathrm{g} / \mathrm{g})$ (Table 2).

\subsection{Pharmacologic properties of MPO}

\section{Anti-inflammatory effects}

The anti-inflammatory properties of MPO were analyzed by examining the migration of neutrophil and mononucleate cells to the peritoneal cavity of mice. As observed in Figure 1A, the oral

Table 1. Physicochemical properties of the MPO.

\begin{tabular}{lc}
\hline \multicolumn{1}{c}{ Parameters } & \multicolumn{1}{c}{ Results } \\
\hline Acidity index (\% oleic acid) & $2.47 \pm 0.03$ \\
Peroxide index (mEq/kg) & $9.28 \pm 0.72$ \\
Iodine index (Wijs) & $72.01 \pm 1.28$ \\
Absorptivity 232 nm & $2.49 \pm 0.04$ \\
Absorptivity 270 nm & $0.64 \pm 0.01$ \\
\hline
\end{tabular}

MPO: macauba pulp oil. The results represent the mean $\pm \mathrm{EPM}$ of the analysis performed in triplicate.

Table 2. Fatty acids profile in MPO and total carotenoids.

\begin{tabular}{lc}
\hline \multicolumn{1}{c}{ Fatty Acid } & $\%$ \\
\hline Capric Acid $\left(\mathrm{C}_{10: 0}\right)$ & 0.15 \\
Mirístic Acid $\left(\mathrm{C}_{14: 0}\right)$ & 0.22 \\
Palmític Acid $\left(\mathrm{C}_{16: 0}\right)$ & 15.80 \\
Palmitoleic Acid $\left(\mathrm{C}_{16: 1}\right)$ & 3.00 \\
Esterasic Acid $\left(\mathrm{C}_{18: 0}\right)$ & 1.51 \\
Elaidic Acid $\left(\mathrm{C}_{18: 1}\right)$ & 4.00 \\
Oleic Acid $\left(\mathrm{C}_{18: 1}\right)$ & 71.76 \\
Linoleic Acid $\left(\mathrm{C}_{18: 2}\right)$ & 1.79 \\
Linolenic Acid $\left(\mathrm{C}_{18: 3}\right)$ & 1.01 \\
Cis-11-Eicosenic Acid $\left(\mathrm{C}_{20: 1}\right)$ & 0.18 \\
Saturate Acids & 18.00 \\
Unsaturate Acids & 82.00 \\
Total carotenoids $(\beta$-carotene $)$ & $694 \pm 8.31 \mu \mathrm{g} / \mathrm{g}$ \\
\hline MPO: macauba pulp oil. &
\end{tabular}

Table 3. Antioxidant activities (\%) of MPO carried out by the scanning method of hydroxyl radical.

\begin{tabular}{lcccc}
\hline & $5 \mu \mathrm{g} / \mathrm{mL}$ & $10 \mu \mathrm{g} / \mathrm{mL}$ & $25 \mu \mathrm{g} / \mathrm{mL}$ & $50 \mu \mathrm{g} / \mathrm{mL}$ \\
\hline Ascorbic Acid & $83.91 \pm 0.24$ & $84.28 \pm 0.36$ & $84.19 \pm 0.32$ & $83.46 \pm 0.09$ \\
MPO & $70.58 \pm 0.22^{*}$ & $69.47 \pm 0.00^{*}$ & $67.48 \pm 0.66^{*}$ & $63.94 \pm 0.22^{*}$ \\
\hline
\end{tabular}

MPO: macauba pulp oil. Determinations were performed after $60 \mathrm{~min}$. The results represent the mean $\pm \mathrm{EPM}$ of the analysis performed in triplicate. ${ }^{*}$ Significantly different when compared with the respective Ascorbic acid control $(\mathrm{p} \leq 0.05)$. ANOVA followed by Bonferroni post-test. 

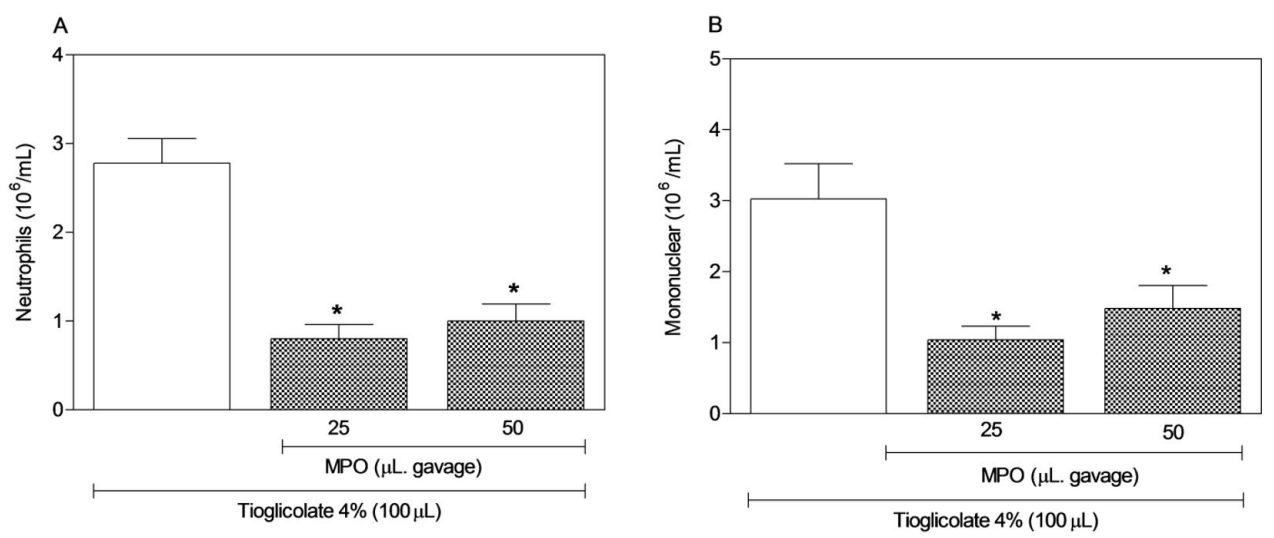

Figure 1. Anti-inflammatory effect of MPO. The anti-inflammatory effect of macauba pulp oil (MPO) was assessed by leukocyte migration into the mice peritoneal cavity. Mice $(\mathrm{n}=5)$ were pre-treated with $\mathrm{MPO}\left(25\right.$ and $50 \mu \mathrm{L}$, gavage) for 10 days. On the $11^{\text {th }}$ day, the inflammatory stimulus (Thioglycolate $4 \%$, i.p.) was injected. Control groups received saline $0.9 \%(200 \mu \mathrm{L}$ i.p). After $6 \mathrm{~h}$, total and differential cell counts were performed. The results are expressed as number of neutrophils and mononuclear cells $x 10^{6}$ (mean \pm SEM) ${ }^{\star} p<0.05$ when compared to the group treated with Thioglycolate. ANOVA followed by Bonferroni post-test.

A

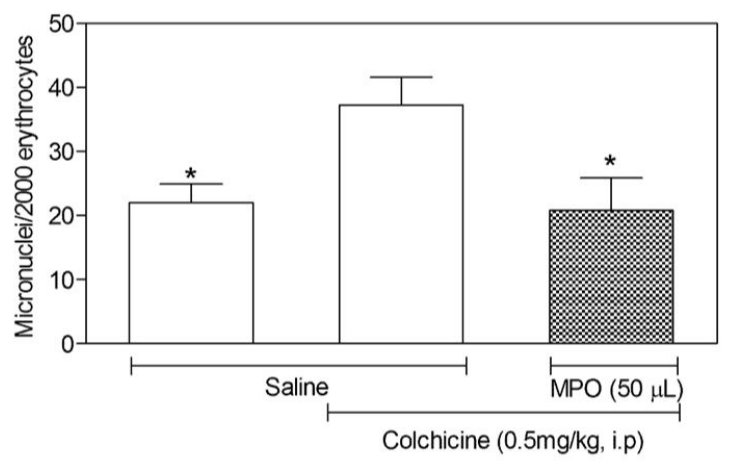

B

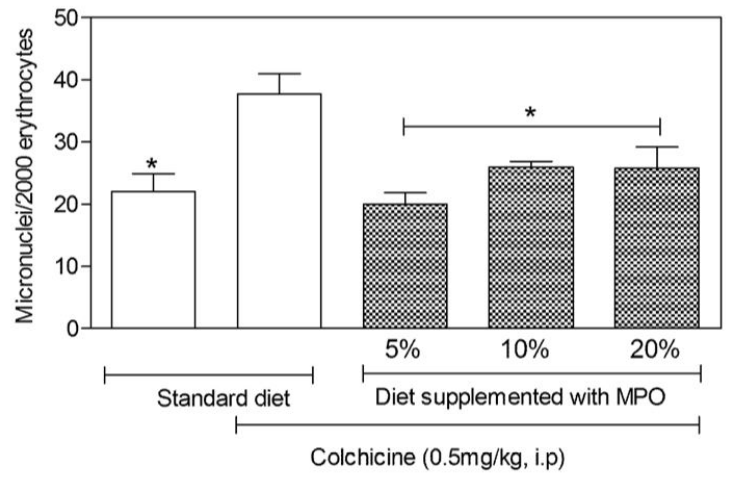

Figure 2. Macauba pulp oil (MPO) provided antimutagenic effect. (Panel A) The animals received $50 \mu \mathrm{L}$ of MPO or saline (gavage) for 10 days. (Panel B) Mice received diet incorporated with $\operatorname{MPO}$ (5, 10 and 20\%, ad libitum) for 10 days. The control group was fed with standard diet. On the $11^{\text {th }}$ day, the mice were treated with colchicine $(0.5 \mathrm{mg} / \mathrm{kg}$, i.p.). After 24 hours the micronucleus frequency in erythrocytes was evaluated. 2000 cells/mouse $(n=5)$ were counted. Results are expressed as mean \pm SEM (standard error of the mean) of the number of micronucleus. ${ }^{*} p<0.05$ when compared to the control group. ANOVA followed by Bonferroni post-test.

administration of 25 and $50 \mu \mathrm{L}$ of MPO for 10 days significantly reduced $(67 \%)$ the neutrophil migration to the peritoneal cavity when compared with the non-treated group. Likewise, MPO administration was able to reduce mononucleate infiltration $(68 \%)$ in inflammatory site (Figure 1B). These findings suggest that MPO presents anti-inflammatory properties.

\section{Antimutagenic effects}

In order to evaluate the antimutagenic effect of MPO, mice were pre-treated with $50 \mu \mathrm{L}$ of oil or saline by gavage for 10 days. The results showed that MPO was able to protect the animals against DNA damage induced by colchicine, since the micronucleus number in erythrocytes from mice treated with MPO was $44 \%$ lower when compared with control group $(\mathrm{p}<0.05)$ (Figure 2A). In order to confirm the protective effect of MPO, the oil was incorporated in the food and mice were fed for 10 days with a diet containing $\mathrm{MPO}$ at different rates of supplementation $(5,10$ and $20 \%)$ and then challenged with colchicine (Figure 2B). Results showed that micronucleus frequency was lower $(45 \%)$ in all MPO concentrations compared to the control $(\mathrm{p}<0.05)$, corroborating the chemoprotective effect of oil consumption.

\subsection{Antioxidant activity and decrease of lipid peroxidation induced by MPO}

In order to test the antioxidant effect of MPO, a combination of in vitro assays was performed: firstly, we used the method of sequestration of hydroxyl radicals, followed by $\beta$-carotene/linoleic acid measurements. Both assays demonstrated remarkable antioxidant properties of MPO when compared to the ascorbic acid and BHT of the control group (Figure 3). The antioxidant activities (\% AA) of the MPO and ascorbic acid, used as control, are described in Table 3. The results show that MPO presented 
A

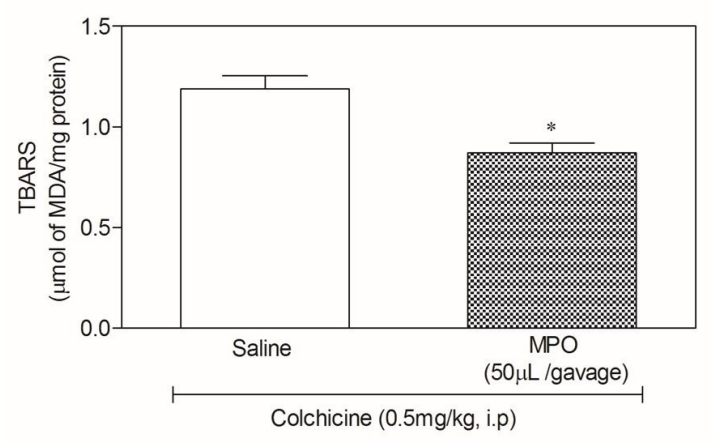

B

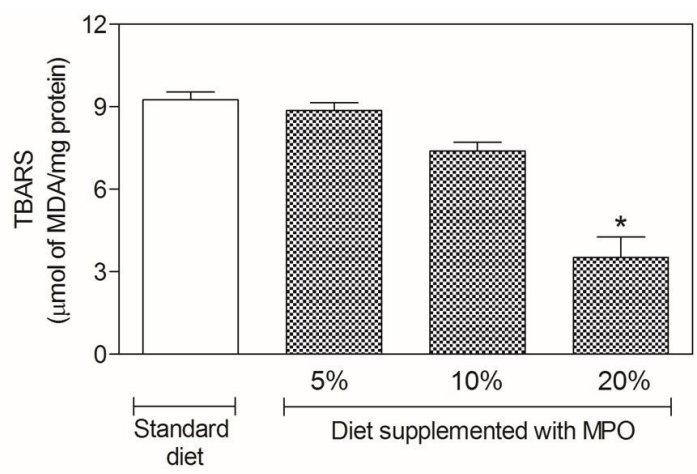

Figure 3. Lipid peroxidation inhibition induced by Macauba pulp oil (MPO). Mice ( $\mathrm{n}=5)$ were pretreated with MPO (5, 10 and $20 \%$, ad libitum) in diet (Panel A) or orally (Panel B) for 10 days. Control group received a standard diet or saline per gavage. On the $11^{\text {th }}$ day, mice were challenged with colchicine $(0.5 \mathrm{mg} / \mathrm{kg}$, i.p.). After 24 hours, they were euthanized and blood sample was collected for evaluation of lipid peroxidation by MDA quantification. Results are expressed as mean \pm SEM (standard error of the mean) of the concentration of $\mu$ mol of MDA/mg protein. ${ }^{\star} p<0.05$ when compared to the control group. ANOVA followed by Bonferroni post-test.

Table 4. Antioxidant activities (\%) of MPO carried out by $\beta$-carotene/linoleic acid assay .

\begin{tabular}{lcccc}
\hline & $5 \mu \mathrm{g} / \mathrm{mL}$ & $10 \mu \mathrm{g} / \mathrm{mL}$ & \multicolumn{1}{c}{$25 \mu \mathrm{g} / \mathrm{mL}$} & \multicolumn{1}{c}{$50 \mu \mathrm{g} / \mathrm{mL}$} \\
\hline BHT & $57.85 \pm 15.03$ & $66.53 \pm 9.91$ & $61.16 \pm 19.21$ & $70.25 \pm 27.17$ \\
MPO & $70.25 \pm 14.87$ & $91.74 \pm 11.24$ & $66.12 \pm 17.37$ & $66.94 \pm 5.72$ \\
\hline
\end{tabular}

Determinations were performed after $60 \mathrm{~min}$. The results represent the mean \pm EPM of the analysis performed in triplicate. Significantly different when compared with the respective Ascorbic acid control ( $\mathrm{p} \leq 0.05$ ). ANOVA followed by Bonferroni post-test.

antioxidant activity similar to ascorbic acid in the range of 5 to $50 \mu \mathrm{g} / \mathrm{mL}$. In addition, an evaluation of the antioxidant properties of MPO as well as oxidation-associated $\beta$-carotene and linoleic acid were also conducted (Table 4). All doses of MPO exhibited antioxidant activity similar to that observed in the control group (BHT).

We also performed lipid peroxidation in the plasma from mice subjected to diet with MPO or MPO by gavage. Mice treated with MPO per gavage presented a decrease in lipid peroxidation (25\%) when compared with control group (Figure 3A). On the other hand, only the animals that received a diet supplemented with MPO 20\% showed reduced (67\%) lipid peroxidation (Figure 3B).

\section{Discussion}

Physical-chemical properties of a virgin plant oil can vary according to the region of cultivation, maturation stadium, storage length and conditions, genetic variability and processing method, among other factors, and may lead to the deterioration of the oil, affecting properties such as sensory quality, nutritional function and toxicity (Ballus et al., 2015; Beltrán et al., 2005). Therefore, MPO was characterized with regard to parameters of quality and identity. The MPO assessed in this study showed acidity and peroxide indexes within the standards for crude palm oil, taken as a reference for MPO, since there is no legal compliance for this oil. Thus, the reference was $5 \%$ oleic acid and $10 \mathrm{mEq} / \mathrm{kg}$ peroxide value (Beltrán et al., 2005). Another reference could be olive oil, whose acidity is established according to the obtaining process (mechanical extraction and / or solvent extraction), whether refined or blended. There are two levels for maximum acidity of olive oil: $3.3 \%$ for virgin olive oil and $0.3 \%$ for refined olive oil (Beltrán et al., 2005; Brasil, 2005). The iodine value is an identity standard of vegetable oils because it accounts for the degree of oil unsaturation. In addition, the iodine value can be used to track oxidation since this reaction changes the number of double bonds of the fatty acids chains. The MPO iodine value found in this work $(72.01 \pm 2.22)$ was very close to the one reported by Prates-Valério et al. (2019). This value is within the recommended standards for olive oil. According to Resolution 22/77/MS, the iodine value for olive oil is supposed to be between 75 and 90 (Brasil, 2005). The similarity of the iodine value of MPO and olive oil is due to the fatty acid profile, which is rich in oleic acid, as discussed below.

Spectrophotometric analysis of oils using ultraviolet wavelength can provide information about their identity, conservation status and changes caused by processing (Tilahun et al., 2019). Molar absorptivity usually correlates positively to peroxide value and is a measurement of conjugated dienes (at $232 \mathrm{~nm}$ ) and trienes (at $270 \mathrm{~nm}$ ) that arose due to the primary oil oxidation process. The MPO showed absorptivity in accordance with the high peroxide value reported in stored macauba fruits (Nunes et al., 2015) and with the trend observed during the refining of MPO (Kiritsakis \& Markakis, 1987). Our results indicated that the MPO had absorptivity (2.49 at $232 \mathrm{~nm}$ and 0.64 at $270 \mathrm{~nm}$ ) similar to that recommended for extra virgin olive oil (2.5 at $232 \mathrm{~nm}$ and 0.22 at $270 \mathrm{~nm}$ ) (Gallardo-Guerrero et al., 2005). The data show that the MPO utilized in this study had high quality and stability, despite its extraction with hexane. We suggest that innovative extraction techniques can produce MPO with improved quality and edible properties.

The fatty acid profile of MPO showed twelve fatty acids, the majority of them unsaturated fatty acids with oleic acid the most abundant (72\%). These results are in agreement with previous reports which describes the presence of oleic and palmitic acid at around $73 \%$ and $16 \%$, respectively, in macauba oil obtained from the fruit of other Brazilian regions (Coimbra \& Jorge, 2011; Lescano et al., 2015; Tilahun et al., 2019). Also, it has 
been reported that several plant oils, such as olive oil, present high levels of monounsaturated acids, similarly observed in MPO (Gallardo-Guerrero et al., 2005; Kiritsakis \& Markakis, 1987; Nissensohn et al., 2016). The consumption of this oil source may be associated with the reduction of risk factors for coronary heart disease, in particular, amelioration of the lipid profile, inhibition of lipid and DNA oxidation, decrease of insulin resistance and inflammation (Estruch et al., 2006; Gillingham et al., 2011; Calder, 2017).

The results observed in this study support that MPO efficiently affects acute inflammation by inhibiting leukocyte migration, which is possibly mediated by one of its main phytochemicals, phenolic compounds and fatty acids, which are able to reduce inflammatory mediators. In this context, several studies demonstrated that polyunsaturated fatty acids exhibit a protective role in health by decreasing pro-inflammatory mediators (Wiktorowska-Owczarek et al., 2015; Ventro et al., 2017). Murumalla et al. (2012) showed that polyunsaturated fatty acids inhibit LPS-induced cytokine secretion, such as IL-6, TNF- $\alpha$, and MCP-1 in both adipose tissue and mature adipocyte models [36]. Similarly, it has also been observed that vegetable oil blend, rich in monounsaturated fatty acids with oleic acid as the major lipid, can exert analgesic and anti-inflammatory activities by down-regulation of the expression of pro-inflammatory cytokines such as TNF- $\alpha$, IL- 6 and NO, as well as the production of free radicals in lipopolysaccharide-stimulated macrophage cells (Guidoni et al., 2019; Zadeh-Ardabili \& Rad, 2019). We showed that $100 \mu \mathrm{L}$ was able to inhibit neutrophil migration to the peritoneal cavity, however, less efficiently than either 25 or $50 \mu \mathrm{L}$ of MPO (Data not shown). The observation that $25 \mu \mathrm{L}$ of MPO is more effective as an anti-inflammatory treatment than higher volumes ( 50 or $100 \mu \mathrm{L}$ ) might be explained by the fact that high doses of lipid, such as palm oil, administered per gavage in mice could damage intestinal barrier integrity, improved intestinal permeability, altered the intestinal microbiota and increased inflammatory cytokine expression (Araújo et al., 2017; Gulhane et al. 2016; Lam et al., 2015; Cani et al., 2008). In addition, increasing levels of saturated palmitic acid, but not unsaturated oleic (Ghezzal et al., 2020), promotes a dual effect of palm oil consumption in metabolic and inflammatory diseases, suggesting that the benefit of palm oil is associated with their moderate dietary intake.

In addition to its anti-inflammatory effects, several in vivo and in vitro reports have shown that $A$. aculeata oil also exhibited absence of acute and sub-acute toxicity in terms of the cytotoxicity, genotoxicity, and mutagenicity (Silva et al., 2019; Traesel et al., 2014, 2015). These observations were also observed in the present study, which showed that MPO prevents antimutagenic effects induced by colchicine.

Oxidative stress induced by free radicals and reactive oxygen/nitrogen species play an important role in several disturbances of health and in pathogenesis (Kehrer \& Klotz, 2015), such as DNA damage and inflammatory disease (Sanjinez-Argandoñ \& Chuba, 2011; Rocha et al., 2013). Since a diet including antioxidants is important for the inhibition of oxidative stress (Sanjinez-Argandoñ \& Chuba, 2011; Rocha et al., 2013), the antioxidant properties of MPO were investigated. We verified that MPO contains high concentrations of total carotenoids expressed as $\beta$-carotene $(694 \pm 8.31 \mu \mathrm{g} / \mathrm{g})$ than observed in previous reports (Coimbra \& Jorge, 2011; Nunes et al., 2015), which is a well-recognized natural antioxidant with potential health benefits (Kehrer \& Klotz, 2015). Our data are supported by previous observation that show that $A$. aculeata pulp is rich in antioxidants such as $\beta$-carotene (Sanjinez-Argandoñ \& Chuba, 2011; Rocha et al., 2013), a-tocopherol (Coimbra \& Jorge, 2011; Schex et al., 2018), and monounsaturated fatty acids such as oleic acid (Ciconini et al., 2013; Mariano et al., 2011). Another line of evidence of the anti-inflammatory properties of A. aculeate oil is based on lipid peroxidation in the plasma from mice subjected to diet with MPO or MPO by gavage. Mice treated with MPO per gavage presented a decrease in lipid peroxidation (25\%) when compared with control group (Figure $3 \mathrm{~A}$ ). In addition, only the animals that received a diet supplemented with $20 \% \mathrm{MPO}$ showed reduced (67\%) lipid peroxidation (Figure 3B). These effects can be due to carotenoids and other antioxidant contents (Rodriguez-Concepcion et al., 2018; Russell, 2004; Duthie et al., 1996) and high concentration of oleic acid (Wang et al., 2019).

Inflammatory disease and DNA damage have been widely associated with oxidative stress (Czarny et al., 2018; Zhang et al., 2019). Therefore, the anti-inflammatory and antimutagenic effects of MPO may be associated with the high quantity of antioxidant compounds, such as carotenoids. In fact, several studies have shown that $\beta$-carotene suppressed LPS-induced release of IL- $1 \beta$, IL-6, and TNF- $\alpha$ by inhibition of the NF- $\kappa B$, JAK2/STAT3, and JNK/p38 MAPK signaling pathways in macrophages (Li et al., 2019). Regarding mutagenesis, it was demonstrated that supplementation with $\alpha$-tocopherol and $\beta$-carotene may protect DNA against oxidative damage, supporting the hypothesis that plant oils, rich in these antioxidants, may have antimutagenic properties (Pool-Zobel et al., 1997; Anter et al., 2010). Additionally, it has been shown that $A$. aculeata oil has chemopreventive effects against damage caused by cyclophosphamide in the male reproductive system of rats, possibly by acting as an antioxidant (Arena et al., 2018). It is important to note that the major dietary sources of tocopherols are vegetable oils, from corn, soybean, sesame, cottonseed, and nut (Wang et al., 2019). Previous reports with other vegetable oils support our results and suggest that the antimutagenic effect of MPO might be correlated with the presence of carotenoids. For example, Umegaki et al. (1994) demonstrated that $\beta$-carotene was able to reduce the formation of micronuclei in human lymphocytes irradiated with low doses of X-rays. Besides, Evangelista et al. (2004) verified the anticlastogenic effect of antioxidant compounds in olive and canola oils, which can act by inhibiting oxidative damage induced by ROS (Evangelista et al., 2004). The antioxidant protection of $\beta$-carotene is mediated by scavenging oxidants such as superoxide and this may result in the decrease in ROS. Thus, we suggest that the antioxidant effects of MPO, which is rich in $\beta$-carotene, may be partly due to its role in the prevention of the free radicals in the testis.

\section{Conclusions}

MPO presents anti-inflammatory and antimutagenic properties and these effects might be associated with its phytonutrient profile, such as its fatty acids, which are rich in oleic acid and 
antioxidant compounds, such as carotenoids. MPO shows a promising potential as an innovative plant oil with improved pharmacological properties and versatile nutritional purposes.

\section{Acknowledgements}

We would like to thank Dr. Angela Alves Nunes for technical support in MPO extraction.

\section{References}

Al-Sabti, K., \& Metcalfe, C. D. (1995). Fish micronuclei for assessing genotoxicity in water. Mutation Research, 343(2-3), 121-135. http:// dx.doi.org/10.1016/0165-1218(95)90078-0. PMid:7791806.

American Oil Chemists' Society - AOCS. (2004). Official methods and recommended practices of the AOCS. Chicago: AOCS Press.

Anter, J., Campos-Sánchez, J., Hamss, R. E., Rojas-Molina, M., MuñozSerrano, A., Analla, M., \& Alonso-Moraga, A. (2010). Modulation of genotoxicity by extravirgin olive oil and some of its distinctive components assessed by use of the Drosophila wing-spot test. Mutation Research, 703(2), 137-142. http://dx.doi.org/10.1016/j. mrgentox.2010.08.012. PMid:20732449.

Araújo, J. R., Tomas, J., Brenner, C., \& Sansonetti, P. J. (2017). Impact of high -fat diet on the intestinal microbiota and small intestinal physiology before and after the onset of obesity. Biochimie, 141, 97106. http://dx.doi.org/10.1016/j.biochi.2017.05.019. PMid:28571979.

Arena, A. C., Jorge, B. C., Silva, M. C., Barros, A. L., Fernandes, A. A. H., Nóbrega, R. H., Martinez, E. R. M., Cardoso, C. A. L., AnselmoFranci, J. A., \& Muzzi, R. M. (2018). Acrocomia aculeata oil: beneficial effects on cyclophosphamide-induced reproductive toxicity in male rats. Andrologia, 50(6), e13028. http://dx.doi.org/10.1111/and.13028. PMid:29744904.

Atmaca, G. (2004). Antioxidant effects of sulfur-containing amino acids. Yonsei Medical Journal, 45(5), 776-788. http://dx.doi.org/10.3349/ ymj.2004.45.5.776. PMid:15515186.

Ballus, C. A., Quirantes-Piné, R., Bakhouche, A., Silva, L. F., Oliveira, A. F., Coutinho, E. F., Croce, D. M., Segura-Carretero, A., \& Godoy, H. T. (2015). Profile of phenolic compounds of Brazilian virgin olive oils by rapid resolution liquid chromatography coupled to electrospray ionisation time-of-flight mass spectrometry (RRLC-ESI-TOFMS). Food Chemistry, 170, 366-377. http://dx.doi.org/10.1016/j. foodchem.2014.08.054. PMid:25306359.

Beltrán, G., Aguilera, M. P., Rio, C. D., Sanchez, S., \& Martinez, L. (2005). Influence of fruit ripening process on the natural antioxidant concentration of Hojiblanca virgin olive oils. Food Chemistry, 89(2), 207-215. http://dx.doi.org/10.1016/j.foodchem.2004.02.027.

Brasil, Ministério da Saúde, Agência Nacional de Vigilância Sanitária. (2005, September 23). Regulamento técnico para óleos vegetais, gorduras vegetais e creme vegetal (Resolução RDC/ANVISA/MS $\mathrm{n}^{\circ} 270$, de 22 setembro de 2005). Diário Oficial [da] República Federativa do Brasil.

Calder, P. C. (2017). Omega-3 fatty acids and inflammatory processes: from molecules to man. Biochemical Society Transactions, 45(5), 1105-1115. http://dx.doi.org/10.1042/BST20160474. PMid:28900017.

Cani, P. D., Bibiloni, R., Knauf, C., Waget, A., Neyrinck, A. M., Delzenne, N. M., \& Burcelin, R. (2008). Changes in gut microbiota control metabolic endotoxemia -induced inflammation in high-fat dietinduced obesity and diabetes in mice. Diabetes, 57(6), 1470-1481. http://dx.doi.org/10.2337/db07-1403. PMid:18305141.
Ciconini, G., Favaro, S. P., Roscoe, R., Miranda, C. H. B., Tapeti, C. F., Miyahira, M. A. M., Bearari, L., Galvani, F., Borsato, A. V., Colnago, L. A., \& Naka, M. H. (2013). Biometry and oil contents of Acrocomia aculeata fruits from the Cerrado and Pantanal biomes in Mato Grosso do Sul, Brazil. Industrial Crops and Products, 45, 208-214. http://dx.doi.org/10.1016/j.indcrop.2012.12.008.

Coimbra, M. C., \& Jorge, N. (2011). Proximate composition of guariroba (Syagrus oleracea), jerivá (Syagrus romanzoffiana) and macaúba (Acrocomia aculeata) palm fruits. Food Research International, 44(7), 2139-2142. http://dx.doi.org/10.1016/j.foodres.2011.03.032.

Covas, M. I., Nyyssönen, K., Poulsen, H. E., Kaikkonen, J., Zunft, H. J., Kiesewetter, H., Gaddi, A., de la Torre, R., Mursu, J., Bäumler, H., Nascetti, S., Salonen, J. T., Fitó, M., Virtanen, J., \& Marrugat, J. (2006). The effect of polyphenols in olive oil on heart disease risk factors: a randomized trial. Annals of Internal Medicine, 145(5), 333-341. http://dx.doi.org/10.7326/0003-4819-145-5-20060905000006. PMid:16954359.

Czarny, P., Wigner, P., Galecki, P., \& Sliwinski, T. (2018). The interplay between inflammation, oxidative stress, DNA damage, DNA repair and mitochondrial dysfunction in depression. Progress in NeuroPsychopharmacology \& Biological Psychiatry, 80(Pt C), 309-321. http://dx.doi.org/10.1016/j.pnpbp.2017.06.036. PMid:28669580.

Duthie, S. J., Ma, A., Ross, M. A., \& Collins, A. R. (1996). Antioxidant supplementation decreases oxidative DNA damage in human lymphocytes. Cancer Research, 56(6), 1291-1295. PMid:8640816.

Esfahani, A., Wong, J. M., Truan, J., Villa, C. R., Mirrahimi, A., Srichaikul, K., \& Kendall, C. W. (2011). Health effects of mixed fruit and vegetable concentrates: a systematic review of the clinical interventions. Journal of the American College of Nutrition, 30(5), 285-294. http://dx.doi. org/10.1080/07315724.2011.10719971. PMid:22081614.

Estruch, R., Martínez-González, M. A., Corella, D., Salas-Salvadó, J., Ruiz-Gutiérrez, V., Covas, M. I., Fiol, M., Gómez-Gracia, E., LópezSabater, M. C., Vinyoles, E., Arós, F., Conde, M., Lahoz, C., Lapetra, J., Sáez, G., \& Ros, E. (2006). Effects of a Mediterranean-style diet on cardiovascular risk factors: a randomized trial. Annals of Internal Medicine, 145(1), 1-11. http://dx.doi.org/10.7326/0003-4819-1451-200607040-00004. PMid:16818923.

Estruch, R., Ros, E., Salas-Salvadó, J., Covas, M. I., Corella, D., Arós, F., Gómez-Gracia, E., Ruiz-Gutiérrez, V., Fiol, M., Lapetra, J., LamuelaRaventos, R. M., Serra-Majem, L., Pintó, X., Basora, J., Muñoz, M. A., Sorlí, J. V., Martínez, J. A., \& Martínez-González, M. A. (2013). Primary prevention of cardiovascular disease with a Mediterranean diet. The New England Journal of Medicine, 368(14), 1279-1290. http://dx.doi.org/10.1056/NEJMoa1200303. PMid:23432189.

Evangelista, C. M., Antunes, L. M., Francescato, H. D., \& Bianchi, M. L. (2004). Effects of the olive, extra virgin olive and canola oils on cisplatin-induced clastogenesis in Wistar rats. Food and Chemical Toxicology, 42(8), 1291-1297. http://dx.doi.org/10.1016/j. fct.2004.03.006. PMid:15207380.

Gallardo-Guerrero, L., Gandul-Rojas, B., Roca, M., \& Mínguez-Mosquera, M. I. (2005). Effect of storage on the original pigment profile of Spanish virgin olive oil. Journal of the American Oil Chemists' Society, 82(1), 33. http://dx.doi.org/10.1007/s11746-005-1039-8.

Ghezzal, S., Postal, B. G., Quevrain, E., Brot, L., Seksik, P., Leturque, A., Thenet, S., \& Carrière, V. (2020). Palmitic acid damages gut epithelium integrity and initiates inflammatory cytokine production. Biochimica et Biophysica Acta. Molecular and Cell Biology of Lipids, 1865(2), 158530. http://dx.doi.org/10.1016/j.bbalip.2019.158530. PMid:31647994.

Gillingham, L. G., Harris-Janz, S., \& Jones, P. J. (2011). Dietary monounsaturated fatty acids are protective against metabolic 
syndrome and cardiovascular disease risk factors. Lipids, 46(3), 209228. http://dx.doi.org/10.1007/s11745-010-3524-y. PMid:21308420.

Guidoni, M., De Christo Scherer, M. M., Figueira, M. M., Schmitt, E. F. P., Almeida, L. C., Scherer, R., Bogusz, S., \& Fronza, M. (2019). Fatty acid composition of vegetable oil blend and in vitro effects of pharmacotherapeutical skin care applications. Brazilian Journal of Medical and Biological Research, 52(2), e8209. http://dx.doi. org/10.1590/1414-431x20188209. PMid:30785481.

Gulhane, M., Murray, L., Lourie, R., Tong, H., Sheng, Y. H., Wang, R., Kang, A., Schreiber, V., Wong, K., Magor, G., Denman, S., Begun, J., Florin, T. H., Perkins, A., Cuiv, P. O., McGuckin, M. A., \& Hasnain, S. Z. (2016). High fat diets induce colonic epithelial cell stress and inflammation that is reversed by IL -22. Scientific Reports, 6(1), 28990. http://dx.doi.org/10.1038/srep28990. PMid:27350069.

Hammerschmidt, P. A., \& Pratt, D. E. (1978). Phenolic antioxidants of dried soybeans. Journal of Food Science, 43(2), 556-559. http:// dx.doi.org/10.1111/j.1365-2621.1978.tb02353.x.

Henderson, A., Galeano, G., \& Bernal, R. (1995). Field guide to the palms of the Americas (pp. 166-167). Princeton: Princeton University Press.

Ju, J., Picinich, S. C., Yang, Z., Zhao, Y., Suh, N., Kong, A. N., \& Yang, C. S. (2010). Cancer-preventive activities of tocopherols and tocotrienols. Carcinogenesis, 31(4), 533-542. http://dx.doi.org/10.1093/carcin/ bgp205. PMid:19748925.

Kehrer, J. P., \& Klotz, L. O. (2015). Free radicals and related reactive species as mediators of tissue injury and disease: implications for health. Critical Reviews in Toxicology, 45(9), 765-798. http://dx.doi. org/10.3109/10408444.2015.1074159. PMid:26610815.

Kiritsakis, A., \& Markakis, P. (1987). Olive oil: a review. Advances in Food Research, 31, 453-482. http://dx.doi.org/10.1016/S00652628(08)60170-6. PMid:3328485.

Lam, Y. Y., Ha, C. W., Hoffmann, J. M., Oscarsson, J., Dinudom, A., Mather, T. J., Cook, D. I., Hunt, N. H., Caterson, I. D., Holmes, A. J., \& Storlien, L. H. (2015). Effects of dietary fat profile on gut permeability and microbiota and their relationships with metabolic changes in mice. Obesity, 23(7), 1429-1439. http://dx.doi.org/10.1002/ oby.21122. PMid:26053244.

Lescano, C. H., Oliveira, I. P., Silva, L. R., Baldivia, D. S., SanjinezArgandoña, E. J., Arruda, E. J., Moraes, I. C. F., \& Lima, F. F. (2015). Nutrients content, characterization and oil extraction from Acrocomia aculeata (Jacq.) Lodd. fruits. African Journal of Food Science, 9(3), 113-119. http://dx.doi.org/10.5897/AJFS2014.1212.

Li, R., Hong, P., \& Zheng, X. (2019). Beta-carotene attenuates lipopolysaccharide-induced inflammation via inhibition of the NFkappaB, JAK2/STAT3 and JNK/p38 MAPK signaling pathways in macrophages. Animal Science Journal, 90(1), 140-148. http://dx.doi. org/10.1111/asj.13108. PMid:30460722.

Marco, G. J. (1968). A rapid method for evaluation of antioxidants. Journal of the American Oil Chemists' Society, 45(9), 594-598. http:// dx.doi.org/10.1007/BF02668958.

Mariano, R. G. B., Silva, C. M., Couri, S., Nogueira, R. I., \& Freitas, S. P. (2011). Partition of free fatty acids in deacidification of macauba pulp oil by liquid-liquid extraction using ethanol/water as solvent. Defectand Diffusion Forum, 312, 554-559. http://dx.doi.org/10.4028/ www.scientific.net/DDF.312-315.554.

Moreno, S. E., Alves-Filho, J. C., Alfaya, T. M., Silva, J. S., Ferreira, S. H., \& Liew, F. Y. (2006). IL-12, but not IL-18, is critical to neutrophil activation and resistance to polymicrobial sepsis induced by cecal ligation and puncture. Journal of Immunology, 177(5), 3218-3224. http://dx.doi.org/10.4049/jimmunol.177.5.3218. PMid:16920961.
Murumalla, R. K., Gunasekaran, M. K., Padhan, J. K., Bencharif, K., Gence, L., Festy, F., Césari, M., Roche, R., \& Hoareau, L. (2012). Fatty acids do not pay the toll: effect of SFA and PUFA on human adipose tissue and mature adipocytes inflammation. Lipids in Health and Disease, 11(1), 175. http://dx.doi.org/10.1186/1476-511X-11-175. PMid:23259689.

Nissensohn, M., Román-Viñas, B., Sánchez-Villegas, A., Piscopo, S., \& Serra-Majem, L. (2016). The effect of the mediterranean diet on hypertension: a systematic review and meta-analysis. Journal of Nutrition Education and Behavior, 48(1), 42-53. http://dx.doi. org/10.1016/j.jneb.2015.08.023. PMid:26483006.

Nunes, A. A., Buccini, D. F., Jaques, J. A. S., Portugal, L. C., Guimarães, R. C. A., Favaro, S. P., Caldas, R. A., \& Carvalho, C. M. E. (2018). Effect of Acrocomia aculeata kernel oil on adiposity in type 2 diabetic rats. Plant Foods for Human Nutrition, 73(1), 61-67. http://dx.doi. org/10.1007/s11130-017-0648-8. PMid:29177992.

Nunes, A. A., Favaro, S. P., Galvani, F., \& Miranda, C. H. B. (2015). Good practices of harvest and processing provide high quality Macauba mesocarp oil. European Journal of Lipid Science and Technology, 117(12), 2036-2043. http://dx.doi.org/10.1002/ejlt.201400577.

Paquot, C. (1979). Standard methods for the analysis of oils, fats and derivatives. France: IUPAC Publications.

Pool-Zobel, B. L., Bub, A., Müller, H., Wollowski, I., \& Rechkemmer, G. (1997). Consumption of vegetables reduces genetic damage in humans: first results of a human intervention trial with carotenoid-rich foods. Carcinogenesis, 18(9), 1847-1850. http://dx.doi.org/10.1093/ carcin/18.9.1847. PMid:9328185.

Poveda, E., Ayala, P., Rodríguez, M., Ordóñez, E., Baracaldo, C., Delgado, W., \& Guerra, M. (2005). Effects of vegetal oil supplementation on the lipid profile of Wistar rats. Biomedica., 25(1), 101-109. http:// dx.doi.org/10.7705/biomedica.v25i1.1331. PMid:15962906.

Prates-Valério, P. P., Celayeta, J. M. F., \& Cren, E. C. (2019). Quality parameters of mechanically extracted edible macauba oils (Acrocomia aculeata) for potential food and alternative industrial feedstock application. European Journal of Lipid Science and Technology, 121(5), 1-8. http://dx.doi.org/10.1002/ejlt.201800329.

Rocha, M. S., Figueiredo, R. W., Araújo, M. A., \& Moreira-Araújo, R. S. (2013). Physical and chemical characterization and antioxidant activity (in vitro) of fruit of the Piaui savanna. Revista Brasileira de Fruticultura, 35, 4.

Rodriguez-Amaya, D. B., \& Kimura, M. (2004). HarvestPlus handbook for carotenoid analysis (HarvestPlus Technical Monograph, No. 2,pp. 2-51). Washington: IFPRI and CIAT.

Rodriguez-Concepcion, M., Avalos, J., Bonet, M. L., Boronat, A., Gomez-Gomez, L., Hornero-Mendez, D., Limon, M. C., MeléndezMartínez, A. J., Olmedilla-Alonso, B., Palou, A., Ribot, J., Rodrigo, M. J., Zacarias, L., \& Zhu, C. (2018). A global perspective on carotenoids: metabolism, biotechnology, and benefits for nutrition and health. Progress in Lipid Research, 70, 62-93. http://dx.doi.org/10.1016/j. plipres.2018.04.004. PMid:29679619.

Russell, R. M. (2004). The enigma of $\beta$-carotene in carcinogenesis: what can be learned from animal studies. The Journal of Nutrition, 134(1), 262-268. http://dx.doi.org/10.1093/jn/134.1.262S. PMid:14704331.

Sanjinez-Argandoñ, E. J., \& Chuba, C. A. M. (2011). Biometrical, physical and chemical characterization of bocaiuva (Acrocomia aculeata (Jacq.) Lodd. ex Mart) palm fruits. Revista Brasileira de Fruticultura, 33, 3.

Scariot, A., Lleras, E., \& Hay, J. D. (1995). Flowering and fruiting phenologies of the palm Acrocomia aculeata: patterns and consequences. Biotropica, 27(2), 168-173. http://dx.doi.org/10.2307/2388992. 
Schex, R., Lieb, V. M., Jiménez, V. M., Esquivel, P., Schweiggert, R. M., Carle, R., \& Steingass, C. B. (2018). HPLC-DAD-APCI/ESI-MSn analysis of carotenoids and $\alpha$-tocopherol in Costa Rican Acrocomia aculeata fruits of varying maturity stages. Food Research International, 105, 645-653. http://dx.doi.org/10.1016/j.foodres.2017.11.041. PMid:29433258.

Silva, P. V. B., Ramiro, M. M., Iriguchi, E. K. K., Corrêa, W. A., Lowe, J., Cardoso, C. A. L., Arena, A. C., Kassuya, C. A. L., \& Muzzi, R. M. (2019). Antidiabetic, cytotoxic and antioxidant activities of oil extracted from Acrocomia aculeata pulp. Natural Product Research, 33(16), 2413-2416. http://dx.doi.org/10.1080/14786419.2018.1446 006. PMid:29488388.

Singer, S. D., Zou, J., \& Weselake, R. J. (2016). Abiotic factors influence plant storage lipid accumulation and composition. Plant Science, 243, 1-9. http://dx.doi.org/10.1016/j.plantsci.2015.11.003. PMid:26795146.

Smirnoff, N., \& Cumbes, Q. J. (1989). Hydroxyl radical scavenging activity of compatible solutes. Phytochemistry, 28(4), 1057-1060. http://dx.doi.org/10.1016/0031-9422(89)80182-7.

Tilahun, W. W., Grossi, J. A. S., Favaro, S. P., Sediyama, C. S., Goulart, S. D. M., Pimentel, L. D., \& Motoike, S. Y. (2019). Increase in oil content and changes in quality of macauba mesocarp oil along storage. Oilseeds \& Fats Crops and Lipids, 26, 2-8. http://dx.doi. org/10.1051/ocl/2019014.

Traesel, G. K., Castro, L. H., Silva, P. V., Muzzi, R. M., Kassuya, C. A., Arena, A. C., \& Oesterreich, S. A. (2015). Assessment of the cytotoxic, genotoxic, and mutagenic potential of Acrocomia aculeata in rats. Genetics and Molecular Research, 14(1), 585-596. http://dx.doi. org/10.4238/2015.January.26.13. PMid:25729994.

Traesel, G. K., Souza, J. C., de Barros, A. L., Souza, M. A., Schmitz, W. O., Muzzi, R. M., Oesterreich, S. A., \& Arena, A. C. (2014). Acute and subacute (28 days) oral toxicity assessment of the oil extracted from Acrocomia aculeata pulp in rats. Food and Chemical Toxicology, 74, 320-325. http://dx.doi.org/10.1016/j.fct.2014.10.026. PMid:25445758.

Umegaki, K., Ikegami, S., Inoue, K., Ichikawa, T., Kobayashi, S., Soeno, N., \& Tomabechi, K. (1994). Beta-carotene prevents X-ray induction of micronuclei in human lymphocytes. The American Journal of Clinical Nutrition, 59(2), 409-412. http://dx.doi.org/10.1093/ ajcn/59.2.409. PMid:8310993.

Ventro, G. J., Yang, Y., Chen, M., \& Harmon, C. M. (2017). The molecular impact of omega 3 fatty acids on hepatic pro-inflammatory cytokine signaling. Journal of Pediatric Surgery, 52(6), 1020-1025. http://dx.doi. org/10.1016/j.jpedsurg.2017.03.031. PMid:28433363.

Wang, J. Y., Zhang, Z., Fang, L., Sun, L., Wang, Y., Liu, Y., Xu, D., Nie, F., \& Gooneratne, R. (2019). Oleic acid alleviates cadmium-induced oxidative damage in rat by its radicals scavenging activity. Biological Trace Element Research, 190(1), 95-100. http://dx.doi.org/10.1007/ s12011-018-1526-4. PMid:30267311.

Wiktorowska-Owczarek, A., Berezińska, M., \& Nowak, J. Z. (2015). PUFAs: structures, metabolism and functions. Advances in Clinical and Experimental Medicine, 24(6), 931-941. http://dx.doi.org/10.17219/ acem/31243. PMid:26771963.

Zadeh-Ardabili, P. M., \& Rad, S. K. (2019). Anti-pain and antiinflammation like effects of Neptune krill oil and fish oil against carrageenan induced inflammation in mice models: current statues and pilot study. Biotechnology Reports, 22(22), e00341. http://dx.doi. org/10.1016/j.btre.2019.e00341. PMid:31061816.

Zhang, X., Wu, X., Hu, Q., Wu, J., Wang, G., Hong, Z., \& Ren, J. (2019). Mitochondrial DNA in liver inflammation and oxidative stress. Life Sciences, 236, 116464. http://dx.doi.org/10.1016/j.lfs.2019.05.020. PMid:31078546. 